\title{
ORGANIZAÇÃO, CATALOGAÇÃO E AUXÍLIO EM ANTROPOMETRIA ÓSSEA.
}

\author{
Letícia G. Peron*, Paola I. Boldrin*, Valmir D. Ramos*, Cristhiane M. Schmidt, Viviane Ulbricht, Luiz Francesquini \\ Jr.
}

\section{Resumo}

O objetivo do presente trabalho é a organização, catalogação e prática em Antropometria óssea. Todas as regras de higienização das ossadas seguiram as normas da vigilância sanitária e a catalogação, organização e auxílio em Antropometria seguiram as normas internacionais vigentes (Coma 1999). Inicialmente houve a organização da coleção (urnas com as ossadas) do laboratório de Antropologia Física Forense prof. Eduardo Daruge. Após a organização dos ossos na forma anatômica foi realizada as fotografias (em sete posições diferentes). Durante estas atividades, foi realizado o envelopamento do crânio articulado com plástico film para a realização das tomografias. Com o cumprimento dessas atividades, os alunos da graduação e pós-graduação foram auxiliados a elaborar futuras fórmulas matemática. Concluiu-se que a contribuição dos alunos do PIBIC EM facilitou o uso e manuseio das ossadas permitindo ao término da catalogação adequar a coleção de ossos com as coleções internacionais.

Palavras-chave:

Antropologia forense, Identificação humana, Antropometria.

\section{Introdução}

A Antropologia física forense (método secundário para identificação humana de acordo com a Interpol 2014) visa facilitar o processo de identificação humana. Para tanto são confeccionadas fórmulas matemáticas em coleções ósseas (distintas para a população de um determinado país e para cada período de tempo) visando determinar o sexo e a ancestralidade e estimar a idade e a estatura.

Objetivos: Organização, catalogação e auxílio em Antropometria óssea.

\section{Resultados e Discussão}

Todas as regras de higienização das ossadas seguiram as normas da vigilância sanitária. E a catalogação, organização e auxílio em Antropometria segue as normas internacionais vigentes (Coma 1999).

No presente estudo os discentes inicialmente organizaram a coleção (urnas com as ossadas, em ordem numérica arábica crescente do número 24 ao número 513). Findo esta etapa iniciaram a catalogação (organização dos ossos na norma anatômica, com inserção de numeração por meio de canetas marcadoras para retroprojetores em todos os ossos). Na sequência realizaram as fotografias (em sete posições diferentes), chegando na Urna de número 321. Durante estas atividades, os Discentes promoviam ainda a articulação da mandíbula com a maxila, com a inserção dos dentes com cera, e na sequência envelopavam o crânio articulado com plástico film para a realização das tomografias. Também puderam ajudar os Discentes da graduação e pós-graduação a medir ossadas para a realização de futuras fórmulas matemáticas. Durante este período, tiveram aulas de identificação humana, curso de fotografia, e prática de antropometria e tomografia computadorizada e realizaram buscas de revistas de literatura em sites específicos (nacionais e internacionais) para execução de pequenas revisões.

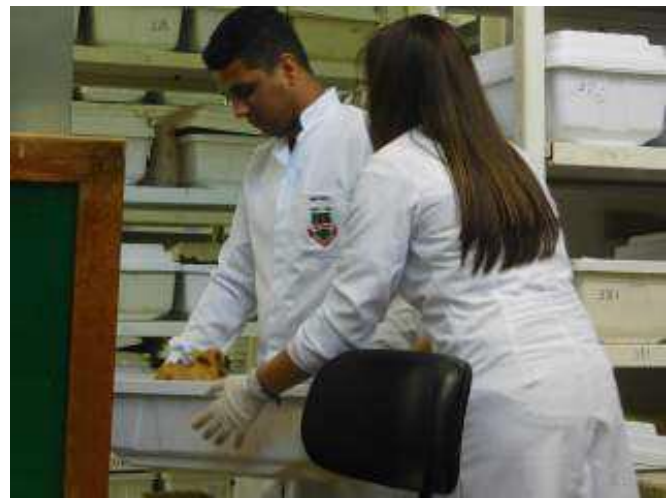

Figura 1. Organização do ossario.

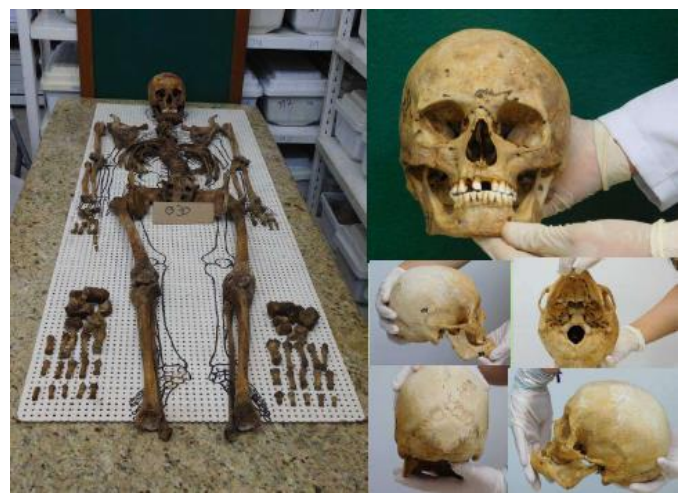

Figura 2. Catalogação e fotografia

\section{Conclusão}

Acredita-se que a contribuição dos alunos do PIBIC EM facilitou o uso e manuseio das ossadas, bem como, agilizou a realização das medições, permitindo ao término da catalogação adequar a coleção de ossos com as coleções internacionais.

\section{Agradecimentos}

Pro reitoria de pesquisa unicamp bolsa pibic ensino médio. 